Федерации, части третьей (постатейный) / под ред. Т.Е. Абовой, М.М. Богуславского, А.Г. Светланова. М.: Юрайт, 2004.486 с.

6. См. Коллини Г.С., Пенцов Д. А. Признание и налогообложение трастов в России. С.40-41.

7. См.: Комментарий к части третьей Гражданского кодекса Российской Федерации (постатейный) /под ред. А.Л. Маковского, Е.А. Суханова / М.: Юристъ, 2002. 538 с.

8. См.: Звеков В.П. Коллизии законов в международном частном праве. М.: Волтерс Клувер, 2007. 416 с.; Толстых В.Л. Международное частное право: коллизионное регулирование. СПб.: Изд-во Р. Асланова «Юридический центр Пресс», 2004. 526 с.

9. См.: Дараселия Г.А. Траст и некоторые вопросы первичной квалификации понятий в международном частном праве // Актуальные проблемы российского права. 2011. № 3. С. $252-261$.

10. Кондратьева Е.М. Актуальные вопросы правовой регламентации использования офшорных компаний и трастов российскими резидентами // Сборник статей международной научнопрактической конференции «Публичное и частное право: конституционные основы и инновационные тенденции» (Стерлитамак, 29.10.2017). Стерлитамак: АМИ, 2017. - С.70-75

11. Путин поддержал предложения по амнистии капиталов// Интернет-портал «Российской газеты».25.03.2015.URL: https://rg.ru/2015/03/25/kapitali-site.html. (Дата обращения: 20.12.2016).

\title{
Коновалов В.А. \\ Методологический подход к раскрытию содержания административно-правового противодействия коррупции
}

Оренбургский институт (филиал) Московского государственного юридического университета имени О.Е. Кутафина (МГЮА) (Россия, Оренбург)

doi:10.18411/spc-20-11-2017-07

idsp: 000001:spc-20-11-2017-07

Административно-правовое противодействие коррупции составляет одно из важнейших направлений антикоррупционной политики государства. Несмотря на сравнительно высокую степень изученности проблемы противодействия коррупции в сфере публичного управления, нельзя говорить о том, что содержание понятия административно-правового противодействия коррупции полностью раскрыто в существующих исследованиях.

Для полного, объективного и точного раскрытия содержания данного понятия необходима соответствующая методологическая база. В качестве основного общенаучного метода исследования мы выбираем диалектико-материалистический подход к анализу содержания понятия административно-правового противодействия коррупции.

Также мы основываем нашу методологию на сравнительно-историческом методе и на общей теории административного права, которые в наибольшей мере соответствуют особенностям исследуемого предмета. Сравнительно-исторический метод, как и социологический подход в исследовании административного права, восходят к исследованиям Л.Штейна. Принципы сравнительно-исторического подхода к раскрытию содержания административно-правового противодействия коррупции включают в себя опору на исследование опыта антикоррупционной работы зарубежных стран и отечественной истории, что позволяет в идеале раскрыть предмет исследования на максимально доказательных и полных основаниях.

При этом мы считаем важным разграничить собственно сравнительноисторический и социологический методы; последний стал одним из преобладающих в исследовании коррупции как таковой, однако он не является подходящим для исследований содержания административно-правового противодействия коррупции, поскольку сосредоточен на обработке первичной социологической информации и, в распространенном виде, страдает методологической односторонностью.

Сравнительно-исторический метод способствует пониманию того, что современное содержание административно-правового противодействия коррупции должно осмысливаться с учетом анализа истории антикоррупционной деятельности в 
нашей стране и других государствах мира. Накопленный опыт по созданию антикоррупционного механизма, политики должен стать основой координации работы по противодействию административной коррупции.

Определенной ценностью обладает, в нашем случае, теория неоинституционализма, согласно которой коррупция в современной России является результатом неформальной институционализации (деформализации), процесса, когда «возникает двойная система управления, в которой начинает преобладать не официальная (формальные институты), а теневая (нефомальные институты) система управления». Этот подход позволяет увидеть проблему содержания административноправового противодействия коррупции как проблему противоречия между формальными и неформальными институтами: если формальные правила легко переменить (реформирование административно-правовой стороны антикоррупционной деятельности), то неформальные правила зачастую более устойчивы, и их преобразование требует долгой и упорной работы, в том числе гибкого и многостороннего административно-правового воздействия. По нашему мнению, теория неоинституционализма значительно влияет на раскрытие содержания административно-правового противодействия коррупции, поскольку с достаточной определенностью детерминирует институциональный характер коррупции.

Поскольку мы считаем доказанным тезис о методологической целесообразности трактовки коррупции с позиций институционального подхода, с тех же позиций, мы считаем, важным раскрывать и содержание административно-правового противодействия коррупции.

Ввиду того, что в современных условиях административная коррупция приобрела свойства многоаспектного социального феномена, административноправовое противодействие коррупции должно отвечать требованиям комплексности. Поскольку понятие коррупции (коррупционных деяний) определяется нами в контексте политического, социально-экономического, правового, идеологического аспектов данного явления, институционально, то и содержание административно-правового противодействия коррупции сложно и многосторонне. Лишь при таком условии будет достигнута максимальная объективность и научность в определении основных направлений и содержания противодействия коррупции административно-правовыми средствами.

Административно-правовое противодействие коррупции может быть определено, с позиций институционального подхода, как механизм противодействия коррупции, основанный на административно-правовом регулировании и направленный на противодействие всем причинам коррупционного поведения. Согласно нашей классификации, приведенной выше, охарактеризуем содержание административноправового противодействия коррупции для каждой из групп причин: экономических, социально-политических и правовых.

В экономическом отношении административно-правовое противодействие коррупции включает:

- правовое предупреждение монополизма и олигархии, хищения средств;

- внедрение общественного гражданского контроля над формированием и расходованием бюджетов;

- налаживание государственной стратегии стимулирования выхода предпринимателей из теневой экономики;

- снижение налоговых ставок.

В социально-политическом отношении

административно-правовое противодействие коррупции включает:

- воспитание культуры демократии в обществе; 
- правовое обеспечение открытости исполнительной власти для общественного контроля;

- развитие правового и гражданского общества;

- сокращение разрыва между населением и исполнительной властью;

- сокращение бюрократического аппарата государства и повышение его эффективности.

Правовое содержание административно-правового противодействия коррупции включает:

- повышение качества законодательства;

- приближение законодательства к реальным условиям жизни;

- мобильность законодательства соответственно требованиям экономической практики;

- выработка четкости процедур правоприменения.

$$
* * *
$$

1. Романова Н.П., Дробышевский В.С. Коррупция: новые подходы // Вестник ЗабГУ. 2012. № 12 (91). C. $80-88$.

2. Боталова Д.Б. Неоинституциональный анализ политической коррупции в российской политической системе // Вестник Красноярского госудрственного педагогического университета им. В.П. Астафьева. 2011. № 2. С. 228-232.

3. Хабриева Т.Я. Проблемы совершенствования законодательства Российской Федерации о противодействие коррупции и практики его применения. 2014 год.

4. Горшенков Г.Н. Принцип научности в антикоррупционной политике // Вопросы российского и международного права. - 2012. - № 2. - С. 85-101.

5. Клюковская И.Н. Антикоррупционная политика как вид правовой политики // Современное право. 2004. № 3. C. 14.

6. Ильяков А.Д. Сравнительно-правовое исследование понятия коррупция // Бизнес в законе. 2013. № 3. C. 89-92.

7. Казанцев Н.М. Институциональные причины российской коррупции и приоритеты политики противодействия ей // Государственная политика противодействия коррупции и теневой экономике в России. Материалы Всероссийской научной конференции (Москва, 6 июня 2007 г.). М., 2007. С. 82.

\section{Коршунова О.Н. \\ Криминалистика в таможенном деле: проблемы и решения \\ Санкт-Петербургский юридический институт (филиал) Академии Генеральной прокуратуры Российской Федерачии (Россия, Санкт-Петербург)}

doi:10.18411/spc-20-11-2017-08

idsp: 000001:spc-20-11-2017-08

В условиях происходящих в Российской Федерации политических и, главное, экономических процессов и преобразований большое значение имеет обеспечение необходимого уровня эффективности функционирования всего государственного механизма. Очевидным представляется то, что соответствующий результат может быть получен только при условии научно обоснованного подхода к определению средств и методов, которые могут способствовать повышению такой эффективности. Сказанное в полной мере относится к деятельности таможенных органов страны. В условиях создания Евразийского экономического союза и подписания Президентом Российской Федерации 14.11.2017 года Федерального закона № 317-Ф3 «О ратификации Договора о Таможенном Кодексе Евразийского экономического союза» определение путей совершенствования таможенной деятельности становится все более актуальным.

Вопросы повышения эффективности деятельности таможенных органов постоянно находятся в поле зрения ученых [3,23-28; 6,67-70]. Справедливой представляется позиция, в соответствии с которой основной тенденцией развития 